\title{
Cannabinoids and Tremor Induced by Motor-related Disorders: Friend or Foe?
}

\author{
Shokouh Arjmand ${ }^{1} \cdot$ Zohreh Vaziri $^{1} \cdot$ Mina Behzadi $^{1} \cdot$ Hassan Abbassian ${ }^{1}$. \\ Gary J. Stephens $^{2} \cdot$ Mohammad Shabani $^{1}$
}

Published online: 8 July 2015

(C) The American Society for Experimental NeuroTherapeutics, Inc. 2015

\begin{abstract}
Tremor arises from an involuntary, rhythmic muscle contraction/relaxation cycle and is a common disabling symptom of many motor-related diseases such as Parkinson disease, multiple sclerosis, Huntington disease, and forms of ataxia. In the wake of anecdotal, largely uncontrolled, observations claiming the amelioration of some symptoms among cannabis smokers, and the high density of cannabinoid receptors in the areas responsible for motor function, including basal ganglia and cerebellum, many researchers have pursued the question of whether cannabinoid-based compounds could be used therapeutically to alleviate tremor associated with central nervous system diseases. In this review, we focus on possible effects of cannabinoid-based medicines, in particular on Parkinsonian and multiple sclerosis-related tremors and the common probable molecular mechanisms. While, at present, inconclusive results have been obtained, future investigations should extend preclinical studies with different cannabinoids to controlled clinical trials to determine potential benefits in tremor.
\end{abstract}

Electronic supplementary material The online version of this article (doi:10.1007/s13311-015-0367-5) contains supplementary material, which is available to authorized users.

Gary J. Stephens

g.j.stephens@reading.ac.uk

Mohammad Shabani

shabani@kmu.ac.ir

1 Kerman Neuroscience Research Center, Neuropharmacology Institute, Kerman University of Medical Sciences, Kerman, Iran

2 School of Pharmacy, University of Reading, Whiteknights, P.O. Box 228, Reading RG6 6AJ, UK
Keywords Tremor · Cannabinoid · Parkinson's disease · Multiple sclerosis $\cdot$ Huntington's disease $\cdot$ Ataxia

Apothecaries were not worth a pin,

If Hemp seed did not bring their commings in; Oyles, Vnguents, Sirrops, Minerals, and Baulmes, (All Natures treasures, and th' Almighties almes,) Emplasters, Simples, Compounds, sundry drugs With Necromanticke names like fearefull Bugs, Fumes, Vomits, purges, that both cures, and kils, Extractions, conserues, preserues, potions, pils, Ellixers, simples, compounds, distillations,

Gums in abundance, brought from foreigne nations.

John Taylor (1580-1653)

For several millennia, many civilizations have used Cannabis sativa for assorted purposes [1]. This magical plant was eulogized for its recreational use and its tremendous beneficial effects in painless surgeries [2, 3]. To date, $>100$ terpenophenolic cannabinoids have been isolated from C. sativa, among these, $\Delta^{9}$-tetrahydrocannabinol $\left(\Delta^{9}\right.$-THC), as the primary and main psychoactive constituent, cannabidiol (CBD), cannabinol, cannabichromene, and cannabigerol are of particular interest [4-6]. In the light of previous studies, the cannabis plant has been shown to play a role as an antiemetic, appetite stimulant, analgesic, euphoriant, anti-inflammatory agent, anticonvulsant, and as a sedative [2, 4, 7-20]. It has also been noted that cannabis can impair memory and cognition $[21,22]$. However, the clinical applications of cannabis remain circumscribed, largely owing to the known psychoactive effects of $\Delta^{9}$-THC $[23,24]$. Cannabinoids exert their pharmacological and physiological activities predominantly through $\mathrm{G}$ protein-coupled cannabinoid $\mathrm{CB}_{1}$ and $\mathrm{CB}_{2}$ receptors $\left(\mathrm{CB}_{1} \mathrm{R}\right.$ and $\mathrm{CB}_{2} \mathrm{R}$, respectively) $[25,26]$. Following the 
discovery of cannabinoid receptors in rat brain in 1980, the location of these receptors was mapped in mammalian species, including humans, and were shown to be ubiquitous in hippocampus, basal ganglia, and cerebellum. Some years later, in 1990 and $1993, \mathrm{CB}_{1} \mathrm{R}$ and $\mathrm{CB}_{2} \mathrm{R}$, respectively, were cloned [27-29]. The predominant expression of these receptors, in particular $\mathrm{CB}_{1} \mathrm{R}$, and the presence of endocannabinoids in brain areas responsible for the management of movements, such as basal ganglia and cerebellum, together with the conspicuous changes in endocannabinoid transmission in the brains of individuals affected by motor disorders, provides a compelling conceptual argument that cannabinoidbased compounds may have the potential to alleviate symptoms of these diseases and provide a novel area of research $[30,31]$. The aim of the current paper is to review the literature on the effects of cannabinoids in motor disorders associated with tremor, with the goal of highlighting possible therapeutic applications. Tremor is a rhythmic, unintentional, oscillatory, and twitching movement, and a clinical manifestation of numerous disorders such as multiple sclerosis (MS), Parkinson's disease (PD), and Huntington's disease (HD), which all affect central areas associated with motor control [32-34]. Tremor has been categorized, based on its etiology, origin, and clinical presentations, into 6 main groups [35]. Despite significant efforts to find an effective pharmacological intervention, as yet there is limited availability of efficient treatments to reduce tremor markedly [36]. However, new insights into the molecular basis of diseases associated with tremor might lead to such a discovery. As argued below, cannabinoids could represent a promising avenue of future research.

\section{Cannabinoid Receptors and Signaling in relations to Central Nervous System Dysfunction Associated with Tremor}

Endocannabinoids are produced "on demand" and act as a retrograde messenger on presynaptic cannabinoid receptors. Although additional molecular targets may be involved, cannabinoid receptors have been divided into 2 major subtypes, $\mathrm{CB}_{1} \mathrm{R}$ and $\mathrm{CB}_{2} \mathrm{R}[26,37]$. While $\mathrm{CB}_{2} \mathrm{R}$ are mostly found in the immune system, $\mathrm{CB}_{1} \mathrm{R}$ are highly expressed and localized to several regions of the brain, with reported expression in neurons, oligodendrocytes, astrocytes, and neural stem cells [38-46]. Owing to this abundance, the potentially greater significance of $\mathrm{CB}_{1}$ Rs will be the focus of this review (Table 1).

The notably high expression of $\mathrm{CB}_{1} \mathrm{R}$ in the cerebellum, in particular on inputs into Purkinje cells from inhibitory basket and stellate interneurons and excitatory climbing fibers arising from granule cells, is indicative of the crucial role of $\mathrm{CB}_{1} \mathrm{R}$ in cerebellar function. Moreover, it has been shown that $\mathrm{CB}_{1} \mathrm{R}$ knockout mice, as well as chronic marijuana users or animals administered $\mathrm{CB}_{1} \mathrm{R}$ agonists, have clear impairment of eyeblink conditioning, an epitome of cerebellar cortex function [47-51]. 2-Arachidonoylglycerol (2-AG) and Narachidonoylethanolamine (AEA), 2 arachidonic acid derivatives, are the chief endocannabinoids in the brain; cerebellum $\mathrm{CB}_{1} \mathrm{R}$ are predominantly activated by $2-\mathrm{AG}$. An increase in the concentration of postsynaptic $\mathrm{Ca}^{2+}$ either by entry via voltagegated $\mathrm{Ca}^{2+}$ channels or activation of type 1 metabotropic glutamate receptors brings about the release of 2-AG synthesized from diacylglycerol, a reaction catalyzed by diacylglycerol lipase-alpha in Purkinje cells, with the overall effect of activation of presynaptic $\mathrm{CB}_{1} \mathrm{R}$ [52-56]. In addition, several studies have reported the high density of $\mathrm{CB}_{1} \mathrm{Rs}$ in striatum and the presence of AEA throughout the basal ganglia, in particular in the globus pallidus and substantia nigra $[31,57,58]$. The crosstalk between dopaminergic transmission and endocannabinoids signaling in the striatum nigra is also well established and there is a growing body of evidence that $\mathrm{CB}_{1} \mathrm{R}$ activation by endocannabinoid retrograde signaling has the potential to decrease glutamate release in a dopaminergic $D_{2}$ receptor-dependent manner [59-61].

\section{Cannabinoids and Tremor in PD}

PD is a progressive neurodegenerative disease affecting basal ganglia and characterized by tremor, rigidity, bradykinesia, and muscle stiffness [62-64]. The piecemeal loss of melanin-containing nigral neurons leads to aberrant dopaminergic transmission, with tremor emerging as a consequence of subthalamic overactivity [64-69]. The increase in the levels of endocannabinoids and alteration in both $\mathrm{CB}_{1} \mathrm{R}$ and $\mathrm{CB}_{2} \mathrm{R}$ expression in different stages of $\mathrm{PD}$ opens the possibility of manipulation of receptor function in the management of disease $[64,70]$. Studies have demonstrated that, in the early stages of $\mathrm{PD}, \mathrm{CB}_{1} \mathrm{R}$ are downregulated, while in advanced and symptomatic phases there is a switch to $\mathrm{CB}_{1} \mathrm{R}$ upregulation [71]. These findings may suggest a basis for use of cannabinoid antagonists in order to alleviate the motor deficits associated with advanced PD. Despite findings supporting this suggestion, Meschler et al. [72] failed to show the proficiency of the $\mathrm{CB}_{1} \mathrm{R}$ antagonist SR141716A (rimonabant) in the mitigation of symptoms in a nonhuman primate model of PD. In another study using tacrin, an acetylcholinesterase inhibitor, to induce Parkinsonian tremor, pretreatment with rimonabant was without significant effect on tremor bursts, whereas, in combination with the adenosine $\mathrm{A}_{2 \mathrm{~A}}$ receptor antagonist, SCH58261, a marked reduced in tremor bursts was seen [73]; however, it is of note that SCH58261 per se produced a pronounced decrease in tremor bursts. Moreover, an early clinic report suggests no advantageous effects of cannabis on tremor among 5 unresponsive patients to anticholinergics and beta blockers [74]. By contrast, a questionnaire-based study revealed a $30.6 \%$ improvement in rest tremor in tremulous 


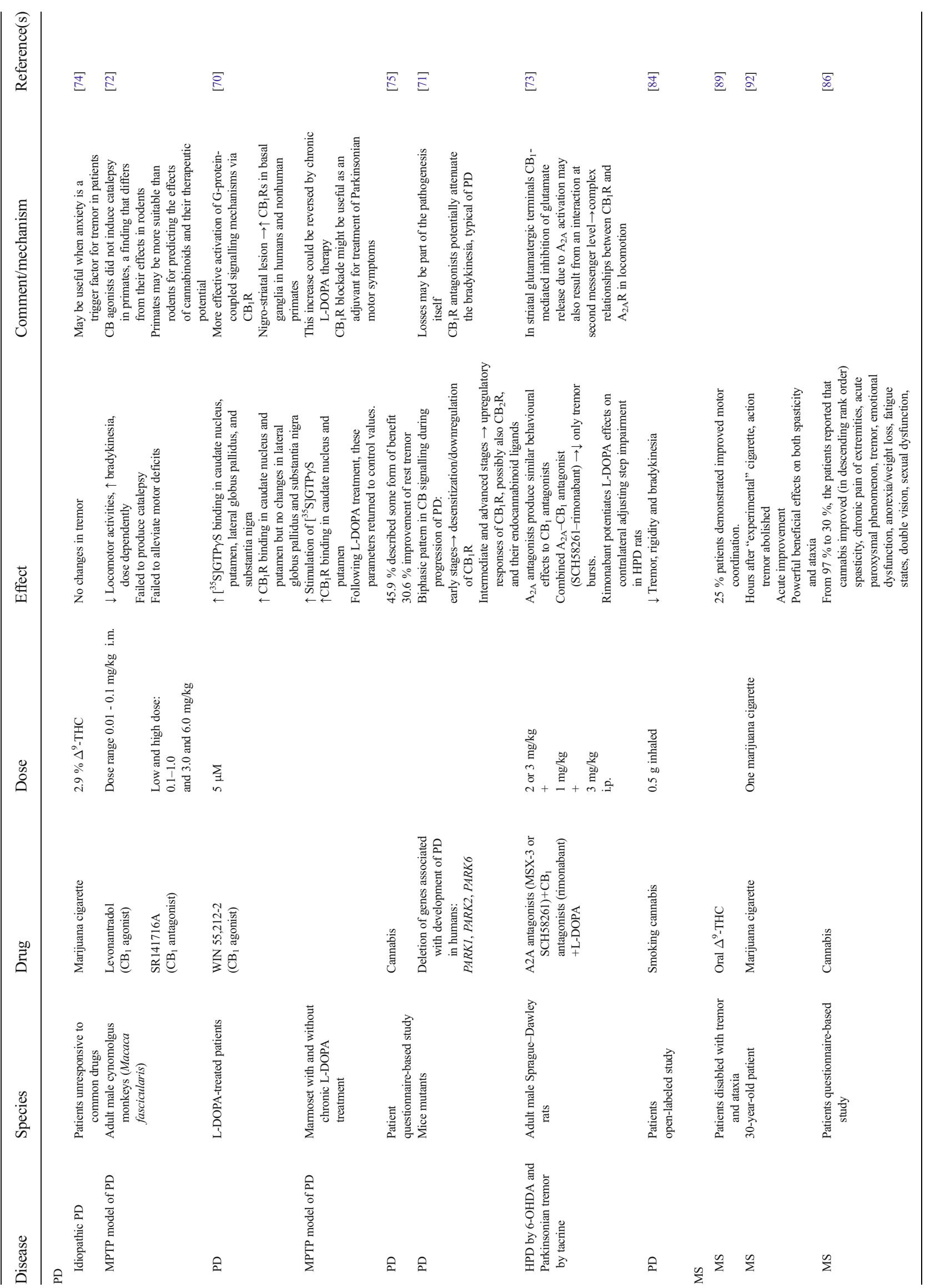




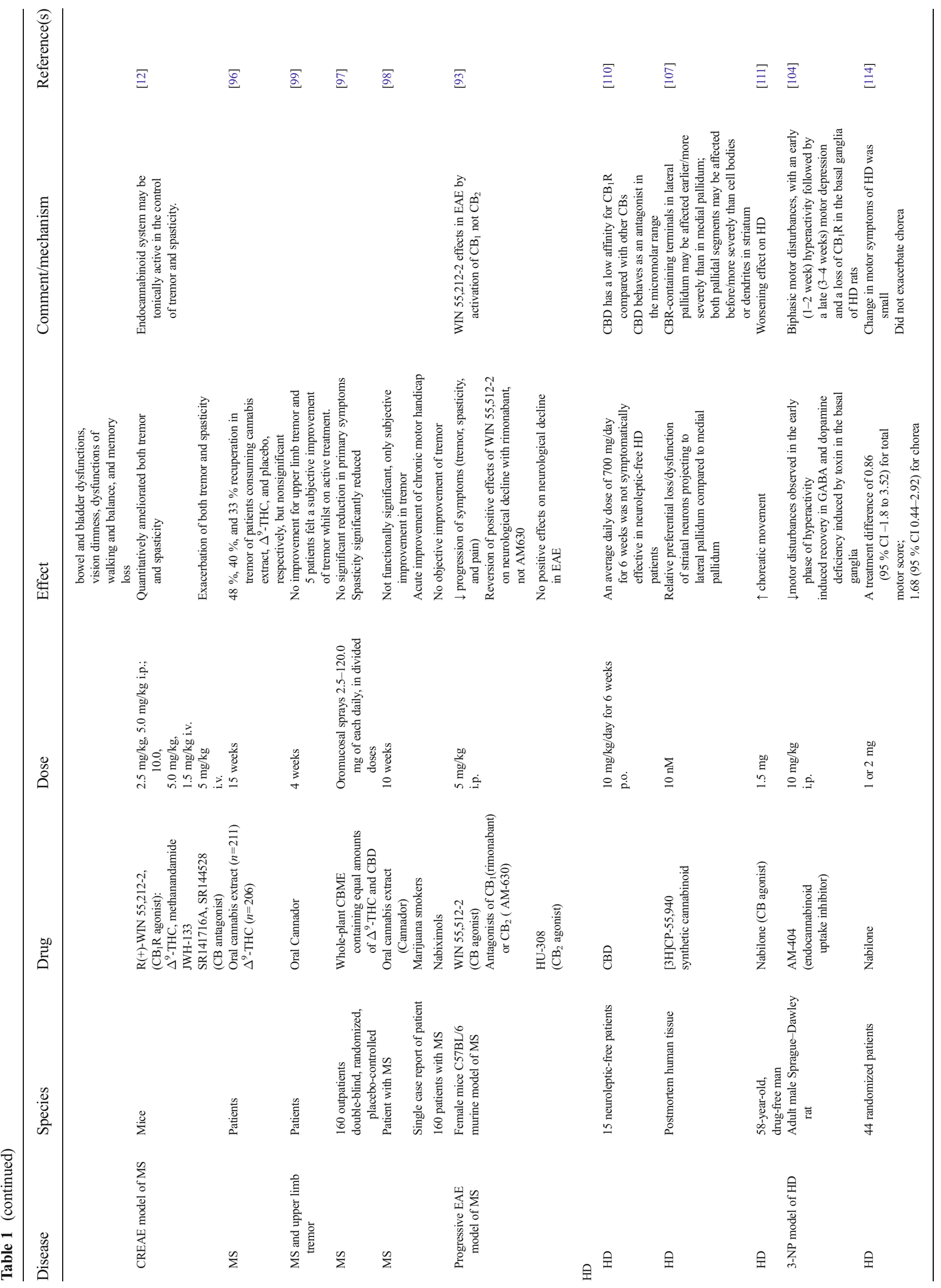




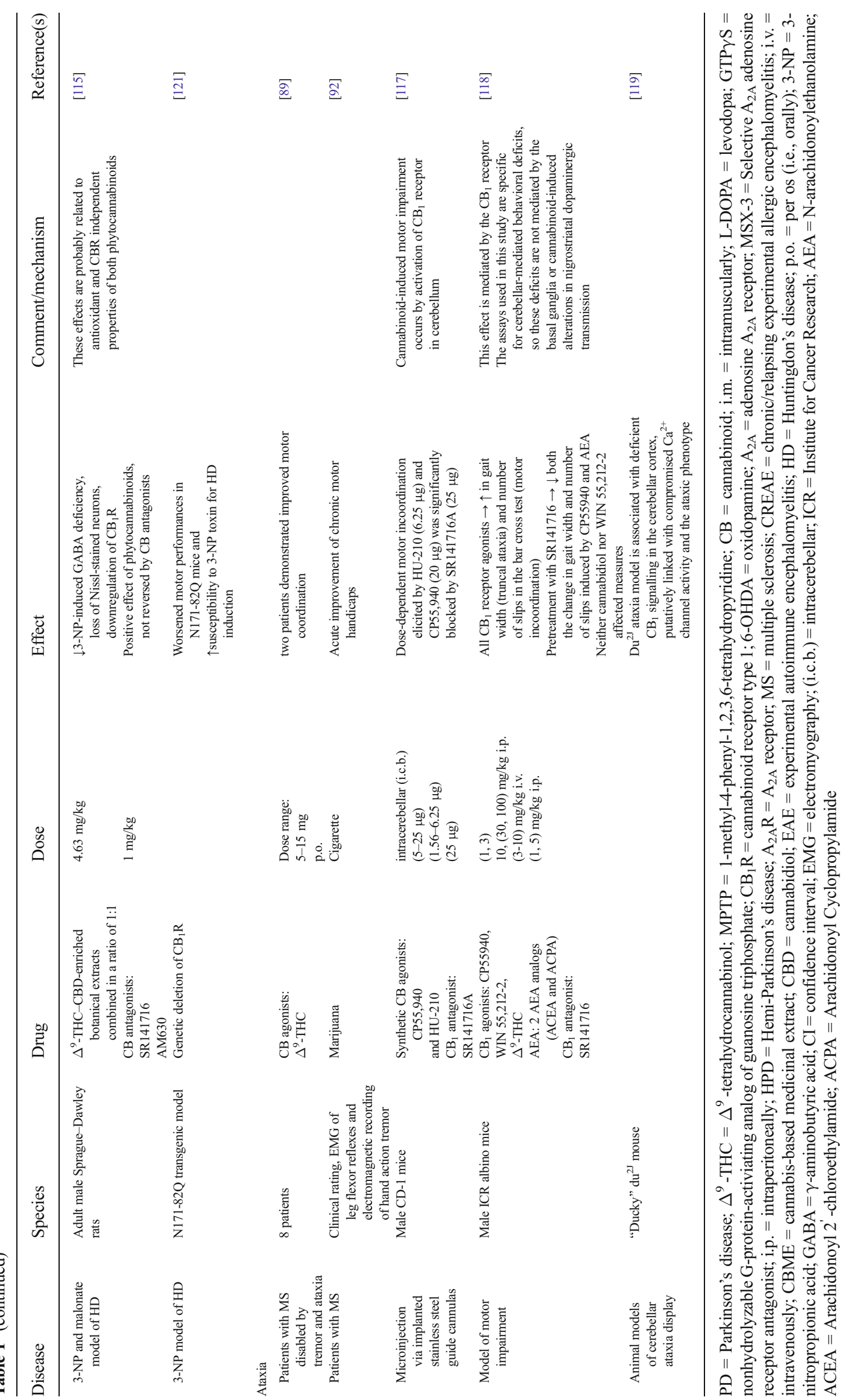


patients with PD [75]. A plausible argument for using cannabinoid agonists as therapeutic agents has arisen from studies describing the inhibitory effect of $\mathrm{CB}_{1} \mathrm{R}$ activation on glutamate release and its capability to oppose subthalamonigral neuronal overactivity and subsequently reduce tremor [64, $76,77]$. It has also been suggested that cannabinoid agonists and endocannabinoids can block dopamine transporters and thereby inhibit dopamine reuptake to ameliorate dyskinesia [78-80]. However, there are other studies asserting no beneficial effects of cannabinoid agonists in alleviation of motor symptoms [75, 81-83].

Unfortunately, there are currently only few double-blind controlled studies and those that have been performed are often paradoxical. In a recent small, open-labeled observational study, the efficacy of cannabis treatment on patients who had experienced severe PD-related pain and tremor, and whose symptoms were insufficiently controlled with current anti-Parkinson medications, was assessed [84]; the results indicated a significant improvement in tremor and rigidity, with a lesser beneficial effect on bradykinesia, among cannabis smokers. Currently, an observational prospective clinical trial is underway to scrutinize the impact of cannabis on PD tremor (ClinicalTrials.gov identifier: NCT02028858); such trials should help advance, and resolve, controversies in this field. Despite these conflicting results, cannabinoid-based compounds should not be neglected as a treatment strategy. It seems that alterations to the endocannabinoid system may play a role in Parkinsonian tremor pathogenesis and that more studies are requisite to consider a further range of individual cannabinoids as potential therapeutic agents for managing signs and symptoms of PD, in particular, tremor.

\section{Cannabinoids and MS-related Tremor}

There is much anecdotal evidence that patients self-medicate with marijuana with the intention of palliating pain, tremor, spasticity, ataxia, and other symptoms associated with MS, an autoimmune disease typified by demyelination and remyelination, and associated with neuroaxonal damage and inflammation [67, 69, 85, 86]. More recent controlled studies, both in animal models of MS and in humans, have begun to validate these preclinical and uncontrolled observations. Involvement of the endocannabinoid system acting at $\mathrm{CB}_{1} \mathrm{R}$ in the pathogenesis of MS have been supported by several studies [87-90]. There are now several lines of evidence indicative of therapeutic potentials of cannabinoids in the control of MSrelated symptoms, including tremor, which remains difficult to manage with current medications (e.g., carbamazepine, propranolol, primidone, and gluthetimide) [12, 89, 91, 92]. Following this premise, De Lago et al. [93] have shown that the nonselective cannabinoid agonist WIN 55,212-2 ameliorated neurological disability, tremor, and spasticity in the chronic relapsing experimental autoimmune encephalomyelitis murine model of MS [92]. Correspondingly, this study revealed the prominent role of $\mathrm{CB}_{1} \mathrm{R}$ activation in the relief of tremor and spasticity, as a selective $C_{1} R$, but not a $C_{2} R$, antagonist reversed the positive effects of preadministered cannabinoids; moreover, no beneficial effects were observed by administering a selective $\mathrm{CB}_{2}$ agonist $[93,94]$. An earlier study reported that cannabinoid agonists $\Delta^{9}$-THC, methanandamide, $\mathrm{R}(+) \mathrm{WIN}$ 55,212-2, and JWH-133 all diminished tremor and spasticity in the experimental autoimmune encephalomyelitis model, and that aggravation of the symptoms occurred after using $\mathrm{CB}_{2} \mathrm{R}$ and, in particular, $\mathrm{CB}_{1} \mathrm{R}$ antagonists [12].

There is also an animal study that supports previous findings which report that chronic, but not acute, $\Delta^{9}$-THC-rich extracts are effective in reducing tremor and spasticity [95]. The "cannabinoids for treatment of spasticity and other symptoms related to multiple sclerosis" (CAMS) study, where 611 of 630 patients were followed, reported $48 \%, 40 \%$, and $33 \%$ recuperation in tremor of patients consuming cannabis extract, $\Delta^{9}$-THC, and placebo, respectively; however, the difference in perception of tremor improvement was not statistically significant [96]. A double-blind randomized placebo controlled study failed to show any favorable effects of a cannabis-based medicinal extract on tremor in a subgroup of 13 patients [97, 98]. In addition, although placebo recipients showed faster finger tapping than that of cannabis extract recipients in a randomized double-blind crossover trial amongst 14 tremulous patients, the study was unable to show any overall marked improvement on measures of objective tremor [99]. In a systematic review published by Koppel et al. [100], oral cannabis extract and $\Delta^{9}$-THC was considered, at present, "probably ineffective" and Sativex (nabiximols) "possibly ineffective" for easing MS-related tremors [100]. Although a decrease in $\mathrm{CB}_{1} \mathrm{R}$ density has been found in caudate-putamen and cortical regions, there are still lack of convincing data on changes to $\mathrm{CB}_{1} \mathrm{R}$ and $\mathrm{CB}_{2} \mathrm{R}$ expression and endocannabinoid transmission in both animals and postmortem brain of patients suffering from MS $[12,101]$.

\section{Cannabinoids and HD-related Tremor}

HD is an autosomal dominant, progressive neurodegenerative disorder primarily affecting cortical and striatal neurons [102, 103]; HD is characterized by chorea, that is, jerky involuntary movements (from the Greek word khoreia meaning "dancing in unison"). The loss of $\mathrm{CB}_{1} \mathrm{R}$ during the progression of $\mathrm{HD}$, most specifically in the lateral pallidum, in transgenic mouse models of HD and in postmortem basal ganglia of patients who suffered from HD, represents a possible justification to investigate the use of cannabinoid agonists in HD [104-107]. While a beneficial response in reducing chorea has been reported for CBD [108], a controlled clinical trial among 15 
patients with HD showed no significant improvements in chorea severity after 6 weeks of CBD administration at an average daily dose of $700 \mathrm{mg} /$ day $[109,110]$. In 2 uncontrolled singlepatient, single-dose studies, nabilone produced opposing effects, worsening the symptoms and increasing choreatic movements in one study, but improving symptoms in the other [111-113]. A recent randomized, double-blind, placebo-controlled, crossover study also indicated the effectiveness of nabilone in the improvement in chorea [114]. It should be pointed out that none of these studies has investigated disease progression and they have all used a single cannabinoid. Therefore, data from animal models suggest either that combinations of different cannabinoids or a broad-spectrum cannabinoid may be needed to justify the lack of positive findings in some of the mentioned studies $[115,116]$.

\section{Ataxia}

Ataxias are a group of related neurological movement disorders that affect coordination, balance, and speech, and can also be associated with tremor. It is well known that cannabinoid agonists can induce motor dysfunction in the cerebellum to give an ataxic phenotype in animals, with effects ameliorated by selective $\mathrm{CB}_{1} \mathrm{R}$ antagonists $[117,118]$. To date, there have been no published clinical trials on effects of cannabinoids in ataxia and potential effects on ataxia are confined to case report data in patients with MS with associated ataxia. Here, oral $\Delta^{9}$-THC or marijuana have been reported to improve motor coordination in some patients with MS [89, 92]. These reports contrast with the clear exacerbating effects of $\mathrm{CB}_{1} \mathrm{R}$ agonists in animals and suggest that investigations with different cannabinoids in patient populations with specific ataxias are needed. In one preclinical model, namely, the "ducky" $d u^{2 J}$ mouse model of ataxia and absence epilepsy, it was found that the prominent $\mathrm{CB}_{1} \mathrm{R}$-mediated inhibition of GABAergic transmission at interneuron-Purkinje cell synapses seen in the wild type was completely absent in heterozygous and homozygous $d u^{2 J}$ mice, despite $\mathrm{CB}_{1} \mathrm{R}$ expression being unchanged [119].$d u^{2 J}$ mice are deficit in the auxiliary $\mathrm{Ca}^{2+}$ channel subunit $\alpha 2 \delta 2$, and these data are consistent with this deficit leading to aberrant $\mathrm{CB}_{1} \mathrm{R}$ signaling downstream of receptor activation; it is also possible that deficits in endocannabinoid modulation of inhibitory transmission in the cerebellum contribute to the ataxic phenotype seen here.

\section{Concluding Remarks}

Cannabinoids, proposed to act predominantly via $\mathrm{CB}_{1} \mathrm{R}$ and $\mathrm{CB}_{2} \mathrm{R}$ activation, have been evaluated for different medical purposes. Cannabinoid receptors and endocannabinoids are highly abundant in the brain areas involved in the management of motor function, and their significant role in modulating many motor functions has been detailed. Although the exact molecular mechanisms of cannabinoid signaling in the pathogenesis of motor-related diseases has not been fully elucidated, and there are significant gaps in our understandings of their influence on motor pathways, medical cannabis appears to have benefits among some patients enduring tremor-associated diseases. However, no studies have so far investigated the role of cannabinoids in essential tremor. At present, despite much anecdotal evidence, observations from case studies and controlled human trials remain poorly matched with those in animal models of diseases. In order to better bridge this gap, it will be important to elucidate mechanisms of cannabinoid action and use comprehensive controlled studies to determine the impact of different cannabinoid-based compounds on tremorrelated diseases in both animal models and humans. Furthermore, many clinical studies have reported psychoactive side effects of cannabinoids and hence their introduction in clinical use remains somewhat controversial. Therefore, there is a need to improve and develop novel therapeutic strategies using cannabinoid-based medicines with fewer side effects. In this regard, non- $\Delta^{9}$-THC cannabinoids may provide an attractive alternative. Moreover, while the above mentioned studies have largely focused on exogenous cannabinoid and endocannabinoid effects on $\mathrm{CB}_{1} \mathrm{R}$ in the central nervous system, it is important to point out that cannabinoid compounds may also act at alternative molecular targets [120]; in particular, the major phytocannabinoid, $\mathrm{CBD}$, has only low, pharmacologically irrelevant, affinity at $\mathrm{CB}_{1} \mathrm{R}$ and is not associated with psychoactive effects. CBD was recent given orphan drug status for Dravet syndrome and warrants further investigation here, as do other non- $\Delta^{9}$-THC phytocannabinoids, to determine which may be friends and which may be foes in the aim of combating tremor. Given the foregoing considerations, it is reasonable to conclude that cannabinoids represent potential candidates for the management of tremor in some patients with motor-related diseases but that more studies should be done in order to elucidate alterations in cell signaling in both basal ganglia and cerebellum of animal models treated with cannabinoids with the aim of reducing tremors.

Acknowledgement We thank Benjamin J. Whalley for his invitation.

Required Author Forms Disclosure forms provided by the authors are available with the online version of this article.

Conflicts of interest GJS has been in receipt of previous funding awards from GW Pharmaceuticals and Ataxia UK. 


\section{References}

1. Giacoppo S, Mandolino G, Galuppo M, et al. Cannabinoids: new promising agents in the treatment of neurological diseases. Molecules 2014;19:18781-18816.

2. Zuardi AW. History of cannabis as a medicine: a review. Rev Bras Psiquiatr 2006;28:153-157.

3. Walker AWH. Indian hemp and insanity in Egypt. BMJ 1983;2:969-969.

4. De Petrocellis L, Ligresti A, Moriello AS, et al. Effects of cannabinoids and cannabinoid-enriched Cannabis extracts on TRP channels and endocannabinoid metabolic enzymes. $\mathrm{Br} J$ Pharmacol 2011;163:1479-1494.

5. El-Alfy AT, Ivey K, Robinson K, et al. Antidepressant-like effect of delta9-tetrahydrocannabinol and other cannabinoids isolated from Cannabis sativa L. Pharmacol Biochem Behav 2010;95: 434-442.

6. Tellioglu T, Celebi F. Synthetic marijuana: a recent turmoil in substance abuse. Bull Clin Psychopharmacol 2014;24:396-404.

7. Walker JM, Huang SM. Cannabinoid analgesia. Pharmacol Ther 2002;95:127-135.

8. Jones NA, Glyn SE, Akiyama S, et al. Cannabidiol exerts anticonvulsant effects in animal models of temporal lobe and partial seizures. Seizure 2012;21:344-352.

9. Martin RS, Luong LA, Welsh NJ, et al. Effects of cannabinoid receptor agonists on neuronally-evoked contractions of urinary bladder tissues isolated from rat, mouse, pig, dog, monkey and human. Br J Pharmacol 2000;129:1707-1715.

10. Marco EM, Viveros MP. [Functional role of the endocannabinoid system in emotional homeostasis]. Rev Neurol 2009;48:20-26 (in Spanish).

11. Järvinen T, Pate DW, Laine K. Cannabinoids in the treatment of glaucoma. Pharmacol Ther 2002;95:203-220.

12. Baker D, Pryce G, Croxford JL, et al. Cannabinoids control spasticity and tremor in a multiple sclerosis model. Nature 2000;404:84-87. d

13. Kumar RN, Chambers WA, Pertwee RG. Pharmacological actions and therapeutic uses of cannabis and cannabinoids. Anaesthesia 2008;56:1059-1068.

14. Florek-Luszczki M, Wlaz A, Kondrat-Wrobel MW, et al. Effects of WIN 55,212-2 (a non-selective cannabinoid CB1 and CB2 receptor agonist) on the protective action of various classical antiepileptic drugs in the mouse $6 \mathrm{~Hz}$ psychomotor seizure model. J Neural Transm 2014;121:707-715.

15. Moulin DE, Clark AJ, Gilron I, Ware MA. Pharmacological management of chronic neuropathic pain - consensus statement and guidelines from the Canadian Pain Society. Pain Res Manag 2007;12:13-21.

16. Devinsky O, Cilio MR, Cross $\mathrm{H}$, et al. Cannabidiol: Pharmacology and potential therapeutic role in epilepsy and other neuropsychiatric disorders. Epilepsia 2014;55:791-802.

17. Russo EB. Cannabinoids in the management of difficult to treat pain. Ther Clin Risk Manag 2008;4:245-259.

18. Fichna J, Bawa M, Thakur GA, et al. Cannabinoids Alleviate experimentally induced intestinal inflammation by acting at central and peripheral receptors. PLoS One 2014;9:e109115.

19. Silva GD, Lopes PS, Fonoff ET, Pagano RL. The spinal antiinflammatory mechanism of motor cortex stimulation: cause of success and refractoriness in neuropathic pain? J Neuroinflammation 2015;12:1-11.

20. Foltin RW. The behavioral pharmacology of anorexigenic drugs in nonhuman primates: 30 years of progress. Behav Pharmacol 2013;23:461-477.
21. Galarreta M, Erdélyi F, Szabó G, Hestrin S. Cannabinoid sensitivity and synaptic properties of 2 GABAergic networks in the neocortex. Cereb Cortex 2008;18:2296-2305.

22. Shabani M, Divsalar K, Janahmadi M. Destructive effects of prenatal WIN 55212-2 exposure on central nervous system of neonatal rats. Addict Health 2012;4:9-19.

23. Wiley JL, Marusich JA, Huffman JW. Moving around the molecule: relationship between chemical structure and in vivo activity of synthetic cannabinoids. Life Sci 2014;97:55-63.

24. Brents LK, Prather PL. The K2/Spice phenomenon: emergence, identification, legislation and metabolic characterization of synthetic cannabinoids in herbal incense products. Drug Metab Rev 2014;46:72-85.

25. Howlett AC. The cannabinoid receptors. Prostaglandins Other Lipid Mediat 2002;68-69:619-631.

26. Pertwee RG. The pharmacology of cannabinoid receptors and their ligands: an overview. Int J Obes (Lond) 2006;30(Suppl. 1):S13-S18.

27. Matsuda LA, Lolait SJ, Brownstein MJ, et al. Structure of a cannabinoid receptor and functional expression of the cloned cDNA. Nature 1990;346:561-564.

28. Griffin G, Tao Q, Abood ME. Cloning and pharmacological characterization of the rat $\mathrm{CB}(2)$ cannabinoid receptor. J Pharmacol Exp Ther 2000;292:886-894.

29. Gérard CM, Mollereau C, Vassart G, Parmentier M. Molecular cloning of a human cannabinoid receptor which is also expressed in testis. Biochem J 1991;279:129-134.

30. Razavinasab M, Shamsizadeh A, Shabani M, et al. Pharmacological blockade of TRPV1 receptors modulates the effects of 6-OHDA on motor and cognitive functions in a rat model of Parkinson's disease. Fundam Clin Pharmacol 2013;27: 632-640.

31. Fernández-Ruiz J, Gonzáles S. Cannabinoid control of motor function at the basal ganglia. Handb Exp Pharmacol 2005;168: 479-507.

32. Bhidayasiri R. Differential diagnosis of common tremor syndromes. Postgrad Med J 2005;81:756-762.

33. Anouti A, Koller WC. Tremor disorders. Diagnosis and management. West J Med 1995;162:510-513.

34. Puschmann AWZ, Puschmann A, Wszolek ZK. Diagnosis and treatment of common forms of tremor. Semin Neurol 2011;31:65-77.

35. Smaga S. Tremor. Am Fam Physician 2003;68:1545-1553.

36. Schneider SA, Deuschl G. The treatment of tremor. Neurotherapeutics 2014;11:128-138.

37. Howlett AC, Breivogel CS, Childers SR, et al. Cannabinoid physiology and pharmacology: 30 Years of progress. Neuropharmacology 2004;47:345-358.

38. Mackie K, Stella N. Cannabinoid receptors and endocannabinoids: evidence for new players. AAPS J 2006;8: E298-E306

39. Marcaggi P. Cerebellar endocannabinoids: retrograde signaling from Purkinje cells. Cerebellum 2015;14:341-353.

40. Aguado T, Monory K, Palazuelos J, et al. The endocannabinoid system drives neural progenitor proliferation. FASEB J 2005;19: 1704-1706.

41. Egertová M, Elphick MR. Localisation of cannabinoid receptors in the rat brain using antibodies to the intracellular $\mathrm{C}$-terminal tail of CB. J Comp Neurol 2000;422:159-171.

42. Herkenham M, Lynn AB, Little MD, et al. Cannabinoid receptor localization in brain. Proc Natl Acad Sci U S A 1990;87:1932-1936.

43. Howlett AC, Barth F, Bonner TI, et al. International Union of Pharmacology. XXVII. Classification of cannabinoid receptors. Pharmacol Rev 2002;54:161-202. 
44. Marsicano G, Goodenough S, Monory K, et al. CB1 cannabinoid receptors and on-demand defense against excitotoxicity. Science 2003;302:84-88.

45. Rodriguez JJ, Mackie K, Pickel VM. Ultrastructural localization of the CB1 cannabinoid receptor in mu-opioid receptor patches of the rat Caudate putamen nucleus. J Neurosci 2001;21:823-833.

46. Molina-Holgado E, Vela JM, Arévalo-Martín A, et al. Cannabinoids promote oligodendrocyte progenitor survival: involvement of cannabinoid receptors and phosphatidylinositol-3 kinase/Akt signaling. J Neurosci 2002;22:9742-9753.

47. Skosnik PD, Edwards CR, O'Donnell BF, et al. Cannabis use disrupts eyeblink conditioning: evidence for cannabinoid modulation of cerebellar-dependent learning. Neuropsychopharmacology 2008;33:1432-1440.

48. Kishimoto Y, Kano M. Endogenous cannabinoid signaling through the CB1 receptor is essential for cerebellum-dependent discrete motor learning. J Neurosci 2006;26:8829-8837.

49. Steinmetz AB, Edwards CR, Vollmer JM, et al. Examining the effects of former cannabis use on cerebellum-dependent eyeblink conditioning in humans. Psychopharmacology (Berl) 2012;221: 133-141.

50. Steinmetz AB, Freeman JH. Central cannabinoid receptors modulate acquisition of eyeblink conditioning. Learn Mem 2010;17:571-576.

51. Yeo CH, Hardiman MJ, Glickstein M. Classical conditioning of the nictitating membrane response of the rabbit. I. Lesions of the cerebellar nuclei. Exp Brain Res 1985;60:87-98.

52. Blankman JL, Cravatt BF. Chemical probes of endocannabinoid metabolism. Pharmacol Rev 2013;65:849-871.

53. Yoshida T, Fukaya M, Uchigashima M, et al. Localization of diacylglycerol lipase-alpha around postsynaptic spine suggests close proximity between production site of an endocannabinoid, 2arachidonoyl-glycerol, and presynaptic cannabinoid CB1 receptor. J Neurosci 2006;26:4740-4751.

54. Tanimura A, Yamazaki M, Hashimotodani Y, et al. The endocannabinoid 2-arachidonoylglycerol produced by diacylglycerol lipase $\alpha$ mediates retrograde suppression of synaptic transmission. Neuron 2010;65:320-327.

55. Ohno-Shosaku T, Kano M. Endocannabinoid-mediated retrograde modulation of synaptic transmission. Curr Opin Neurobiol 2014;29:1-8.

56. Gao Y, Vasilyev DV, Goncalves MB, et al. Loss of retrograde endocannabinoid signaling and reduced adult neurogenesis in diacylglycerol lipase knock-out mice. J Neurosci 2010;30: 2017-2024

57. Di Marzo V, Breivogel CS, Tao Q, et al. Levels, metabolism, and pharmacological activity of anandamide in $\mathrm{CB}(1)$ cannabinoid receptor knockout mice: evidence for non- $\mathrm{CB}(1)$, non- $\mathrm{CB}(2)$ receptor-mediated actions of anandamide in mouse brain. $\mathrm{J}$ Neurochem 2000;75:2434-2444.

58. Herkenham M, Lynn A, Johnson M, et al. Characterization and localization of cannabinoid receptors in rat brain: a quantitative in vitro autoradiographic study. J Neurosci 1991;11:563-583.

59. Pertwee RG, Howlett a C, Abood ME, et al. International Union of Basic and Clinical Pharmacology. LXXIX. Cannabinoid receptors and their ligands: Beyond CB1 and CB2. Pharmacol Rev 2010;62: 588-631.

60. Calabresi P, Picconi B, Tozzi A, et al. Direct and indirect pathways of basal ganglia: a critical reappraisal. Nat Neurosci 2014;17:1022-1030.

61. Van Der Stelt M, Di Marzo V. The endocannabinoid system in the basal ganglia and in the mesolimbic reward system: implications for neurological and psychiatric disorders. Eur J Pharmacol 2003;480:133-150.

62. Sethi KD. Clinical aspects of Parkinson disease. Curr Opin Neurol 2002;15:457-460.
63. Farlow J, Pankratz ND, Wojcieszek J, Foroud T. Parkinson disease overview. In: Pagon RA, Adam MP, Ardinger HH, et al. (eds) GeneReviews ${ }^{\circledR}$ [Internet]. Seattle, WA: University of Washington; 1993-2015. 2004 May 25 [updated 2014 Feb 27].

64. García-Arencibia M, García C, Fernández-Ruiz J. Cannabinoids and Parkinson's disease. CNS Neurol Disord Drug Targets 2009;8:432-439.

65. Blandini F, Nappi G, Tassorelli C, Martignoni E. Functional changes of the basal ganglia circuitry in Parkinson's disease. Prog Neurobiol 2000;62:63-88.

66. Schapira AHV, Tolosa E. Molecular and clinical prodrome of Parkinson disease: implications for treatment. Nat Rev Neurol 2010;6:309-317.

67. Chiurchiù V, Maccarrone M. Chronic inflammatory disorders and their redox control: from molecular mechanisms to therapeutic opportunities. Antioxid Redox Signal 2011;15:2605-2641.

68. Romero J, Lastres-Becker I, de Miguel R, et al. The endogenous cannabinoid system and the basal ganglia. biochemical, pharmacological, and therapeutic aspects. Pharmacol Ther 2002;95:137-152.

69. Chiurchiù V, Leuti A, Maccarrone M. Cannabinoid signaling and neuroinflammatory diseases: a melting pot for the regulation of brain immune responses. J Neuroimmune Pharmacol 2015;10: 268-280.

70. Lastres-Becker I, Cebeira M, de Ceballos ML, et al. Increased cannabinoid CB1 receptor binding and activation of GTPbinding proteins in the basal ganglia of patients with Parkinson's syndrome and of MPTP-treated marmosets. Eur J Neurosci 2001;14:1827-1832.

71. García-Arencibia M, García C, Kurz A, et al. Cannabinoid CB1 receptors are early downregulated followed by a further upregulation in the basal ganglia of mice with deletion of specific park genes. J Neural Transm Suppl 2009;(73):269-275.

72. Meschler JP, Howlet TAC, Madras BK. Cannabinoid receptor agonist and antagonist effects on motor function in normal and 1-methyl-4-phenyl-1,2,5,6-tetrahydropyridine (MPTP)-treated non-human primates. Psychopharmacology (Berl) 2001;156:79-85.

73. Pinna A, Bonaventura J, Farré D, et al. L-DOPA disrupts adenosine A2A-cannabinoid CB1-dopamine D2 receptor heteromer cross-talk in the striatum of hemiparkinsonian rats: Biochemical and behavioral studies. Exp Neurol 2014;253:180-191.

74. Frankel JP, Hughes A, Lees AJ, Stern GM. Marijuana for parkinsonian tremor. J Neurol Neurosurg Psychiatry 1990;53:436.

75. Venderová K, Ružička E, Vorřísšek V, Višňovský P. Survey on cannabis use in Parkinson's disease: Subjective improvement of motor symptoms. Mov Disord 2004;19:1102-1106.

76. Sañudo-Peña MC, Tsou K, Walker JM. Motor actions of cannabinoids in the basal ganglia output nuclei. Life Sci 1999;65:703-713.

77. Sañudo-Peña MC, Patrick SL, Khen S, et al. Cannabinoid effects in basal ganglia in a rat model of Parkinson's disease. Neurosci Lett 1998;248:171-174.

78. Price DA, Owens WA, Gould GG, et al. CB1-independent inhibition of dopamine transporter activity by cannabinoids in mouse dorsal striatum. J Neurochem 2007;101:389-396.

79. Chen N, Appell M, Berfield JL, Reith MEA. Inhibition by arachidonic acid and other fatty acids of dopamine uptake at the human dopamine transporter. Eur J Pharmacol 2003;478:89-95.

80. Heumann R, Moratalla R, Herrero MT, et al. Dyskinesia in Parkinson's disease: Mechanisms and current nonpharmacological interventions. J Neurochem 2014;130:472-489.

81. Müller-Vahl KR, Kolbe H, Schneider U, Emrich HM. Cannabis in movement disorders. Forsch Komplementarmed 1999;6(Suppl. 3):23-27. 
82. Consroe P. Brain cannabinoid systems as targets for the therapy of neurological disorders. Neurobiol Dis 1998;5:534-551.

83. Samuel M, Rodriguez-Oroz M, Antonini A, et al. Management of impulse control disorders in Parkinson's disease: controversies and future approaches. Mov Disord 2015;30:150-159.

84. Lotan I, Treves TA, Roditi Y, Djaldetti R. Cannabis (medical marijuana) treatment for motor and non-motor symptoms of Parkinson disease. Clin Neuropharmacol 2014;37:41-44.

85. Compston A, Coles A. Multiple sclerosis. Lancet 2008;372: 1502-1517.

86. Consroe P, Musty R, Rein J, et al. The perceived effects of smoked cannabis on patients with multiple sclerosis. Eur Neurol 1997;38: 44-48.

87. Ungerleider JT, Andyrsiak T, Fairbanks L, et al. Delta-9-THC in the treatment of spasticity associated with multiple sclerosis. Adv Alcohol Subst Abuse 1987;7:39-50.

88. Martyn CN, Illis LS, Thom J. Nabilone in the treatment of multiple sclerosis. Lancet 1995;345:579.

89. Clifford DB. Tetrahydrocannabinol for tremor in multiple sclerosis. Ann Neurol 1983;13:669-671.

90. Cabranes A, Venderova K, de Lago E, et al. Decreased endocannabinoid levels in the brain and beneficial effects of agents activating cannabinoid and/or vanilloid receptors in a rat model of multiple sclerosis. Neurobiol Dis 2005;20:207-217.

91. Koch M, Mostert J, Heersema D, De Keyser J. Tremor in multiple sclerosis. J Neurol 2007;254:133-145.

92. Meinck HM, Schönle PW, Conrad B. Effect of cannabinoids on spasticity and ataxia in multiple sclerosis. J Neurol 1989;236:120-122.

93. De Lago E, Moreno-Martet M, Cabranes A, et al. Cannabinoids ameliorate disease progression in a model of multiple sclerosis in mice, acting preferentially through CB1 receptor-mediated antiinflammatory effects. Neuropharmacology 2012;62:2299-2308.

94. Kluger B, Triolo P, Jones W, Jankovic J. The therapeutic potential of cannabinoids for movement disorders. Mov Disord 2015;30: 313-327.

95. Buccellato E, Carretta D, Utan A, et al. Acute and chronic cannabinoid extracts administration affects motor function in a CREAE model of multiple sclerosis. J Ethnopharmacol 2011;133:1033-1038.

96. Zajicek J, Fox P, Sanders H, et al. Cannabinoids for treatment of spasticity and other symptoms related to multiple sclerosis (CAMS study): Multicentre randomised placebo-controlled trial. Lancet 2003;362:1517-1526.

97. Wade DT, Makela P, Robson P, et al. Do cannabis-based medicinal extracts have general or specific effects on symptoms in multiple sclerosis? A double-blind, randomized, placebo-controlled study on 160 patients. Mult Scler 2004;10:434-441.

98. Zajicek JP, Apostu VI. Role of cannabinoids in multiple sclerosis. CNS Drugs 2011;25:187-201.

99. Fox P, Bain PG, Glickman S, et al. The effect of cannabis on tremor in patients with multiple sclerosis. Neurology 2004;62: 1105-1109.

100. Koppel BS, Brust JCM, Fife T, et al. Systematic review: Efficacy and safety of medical marijuana in selected neurologic disorders: report of the Guideline Development Subcommittee of the American Academy of Neurology. Neurology 2014;82:1556-1563.

101. Berrendero F, Sanchez A, Cabranes A, et al. Changes in cannabinoid $\mathrm{CB} 1$ receptors in striatal and cortical regions of rats with experimental allergic encephalomyelitis, an animal model of multiple sclerosis. Synapse 2001;41:195-202.
102. Martin JB. Huntington's disease: new approaches to an old problem. The Robert Wartenberg lecture. Neurology 1984;34: 1059-1072.

103. Folstein SE, Leigh RJ, Parhad IM, Folstein MF. The diagnosis of Huntington's disease. Neurology 1986;36:1279-1283.

104. Lastres-Becker I, Hansen HH, Berrendero F, et al. Alleviation of motor hyperactivity and neurochemical deficits by endocannabinoid uptake inhibition in a rat model of Huntington's disease. Synapse 2002;44:23-35.

105. Pazos MR, Sagredo O, Fernández-Ruiz J. The endocannabinoid system in Huntington's disease. Curr Pharm Des 2008;14:2317-2325.

106. Makowiecka J, Wielgus K. Therapeutic potential of cannabinoids - perspectives for the future. J Nat Fibers 2014;11:283-311.

107. Richfield EK, Herkenham M. Selective vulnerability in Huntington's disease: preferential loss of cannabinoid receptors in lateral globus pallidus. Ann Neurol 1994;36:577-584.

108. Sandyk R, Consroe P, Stern LZ, et al. Effects of cannabidiol in Huntington's disease. Neurology 1986;36:342.

109. Zhornitsky S, Potvin S. Cannabidiol in humans - the quest for therapeutic targets. Pharmaceuticals 2012;5:529-552.

110. Consroe P, Laguna J, Allender J, et al. Controlled clinical trial of cannabidiol in Huntington's disease. Pharmacol Biochem Behav 1991;40:701-708.

111. Muller-Vahl KR, Schneider U, Emrich HM. Nabilone increases choreatic movements in Huntington's disease. Mov Disord 1999; 14:1038-1040.

112. Curtis A, Rickards H. Nabilone could treat chorea and irritability in Huntington's disease. J Neuropsychiatry Clin Neurosci 2006; 18:553-554.

113. Chesher GB, Consroe P, Musty RE. Marijuana: an international research report. In: Proceedings of the Melbourne Symposium on Cannabis, 2-4 September 1987. Government Publishing Service, Canberra, 1988.

114. Curtis A, Mitchell I, Patel S, et al. A pilot study using nabilone for symptomatic treatment in Huntington's disease. Mov Disord 2009;24:2254-2259.

115. Sagredo O, Pazos MR, Satta V, et al. Neuroprotective effects of phytocannabinoid-based medicines in experimental models of Huntington's disease. J Neurosci Res 2011;89: 1509-1518.

116. Sagredo O, Ruth Pazos M, Valdeolivas S, Fernandez-Ruiz J. Cannabinoids: novel medicines for the treatment of Huntington's disease. Recent Pat CNS Drug Discov 2012;7:41-48.

117. DeSanty KP, Dar MS Cannabinoid-induced motor incoordination through the cerebellar $\mathrm{CB}(1)$ receptor in mice. Pharmacol Biochem Behav 2001;69:251-259.

118. Patel S, Hillard CJ. Cannabinoid CB(1) receptor agonists produce cerebellar dysfunction in mice. J Pharmacol Exp Ther 2001;297: 629-637.

119. Wang X, Whalley BJ, Stephens GJ. The du(2J) mouse model of ataxia and absence epilepsy has deficient cannabinoid $\mathrm{CB}_{1}$ receptor-mediated signalling. J Physiol 2013;591:3919-3933.

120. Hill AJ, Williams CM, Whalley BJ, Stephens GJ. Phytocannabinoids as novel therapeutic agents in CNS disorders. Pharmacol Ther 2012;133:79-97.

121. Mievis S, Blum D, Ledent C. Worsening of Huntington disease phenotype in CB1 receptor knockout mice. Neurobiol Dis 2011;42:524-529. 